\title{
Consensus of the Ibero-American Oculoplastic Society for selecting the ideal orbital implant in the anophthalmic socket
}

\section{Consenso de la Sociedad Iberoamericana de Oculoplástica para la selección del implante ideal en la cavidad anoftálmica}

\author{
Enrique G. Padilla-García ${ }^{1}$, Rocío Ardito ${ }^{2}$, Alejandra Valenzuela-Arellano ${ }^{3}$, Alfredo Medina ${ }^{4}$, \\ Ana M. Vera-Torres ${ }^{5}$ and Gerardo Graue-Moreno ${ }^{1 *}$ \\ ${ }^{1}$ Orbit and Oculoplastic Department, Fundación Hospital Nuestra Señora de la Luz IAP, Mexico City, Mexico; ${ }^{2}$ Clínica Ardito Oculoplástica, Lima, \\ Peru; ${ }^{3}$ Wake Forest Baptist Health, Winston, Salem, North Carolina, USA; ${ }^{4}$ Hospital Regional Lic. Adolfo López Mateos, Instituto de Seguridad y \\ Servicios Sociales de los Trabajadores del Estado (ISSSTE), Mexico City, Mexico; ${ }^{5}$ Asociación para Evitar la Ceguera, Hospital Dr. Luis Sánchez \\ Bulnes, Mexico City, Mexico
}

\begin{abstract}
Objective: To propose a guide for selecting the ideal orbital implant in the anophthalmic socket by a group of experts in orbit and oculoplastics, members of the Ibero-American Society of Oculoplastics (SIAO). Expert Panel: Rocío Ardito, MD (Perú), Alejandra Valenzuela, MD (USA), Alfredo Medina, MD (Mexico). Moderator: Ana Vera, MD (Colombia). Room Commissioners: Enrique Padilla MD, Gerardo Graue MD. Methods: An interactive, guided discussion was held between the expert panel and attendees to the VI Ibero-American Society of Oculoplastics meeting, held at the "Hospital Nuestra Sra. De la Luz I.A.P.' in Mexico City on October 23, 2018, presenting evidence-based and personal experience for choosing the ideal orbital implant in the anophthalmic socket. The meeting was attended by around 200 specialists in Oculoplastics from North, Central and South America as well as from Spain and Portugal. The discussion was centered on the following subtopics: Type of orbital implants, surgical management, surgical management of anophthalmos and cryptophtalmos, alternatives for orbital implants. Conclusions: Acrylic implants are placed more frequently for rehabilitation of the anophthalmic socket among SIAO members since they demonstrate good, long lasting results and minor complications. Migration is their main complication, making rehabilitation complex when present. Dermis-fat grafts in children and micro free orbital fat grafts in adults are good alternatives for hypo-volumetric orbits.
\end{abstract}

Key words: Anophthalmic socket. Evisceration. Enucleation. Implant. Prosthesis.

\section{Resumen}

Objetivo: Proponer una guía para la elección del implante ideal en la cavidad anoftálmica por parte de un grupo de expertos enórbita y oculoplástica, miembros de la Sociedad Iberoamericana de Oculoplástica(SIAO). Panel de expertos: Dr. RocíoArdito (Perú), Dra. Alejandra Valenzuela (EE.UU.), Dr. Alfredo Medina (México). Moderadora: Dr. Ana Vera (Colombia). Comisarios de sala y recopiladores: Dr. Enrique Padilla García (México), Dr. Gerardo Graue Moreno (México). Metodología: Se realizó

\section{Correspondence:}

*Gerardo Graue-Moreno

Ezequiel Montes, 135

Col. Tabacalera, Del. Cuauhtémoc Date of reception: 03-04-2019 CP 06030, Mexico City, Mexico

E-mail: g.graue@gmail.com
Available online: 02-01-2020 Date of acceptance: 30-07-2019 DOI: 10.24875/RMOE.M20000095
Rev Mex Oftalmol (Eng). 2020;94(1):1-4

www.rmo.com.mx 2604-1731/@ 2020 Sociedad Mexicana de Oftalmología. Published by Permanyer. This is an open access article under the CC BY-NC-ND license (http:// creativecommons.org/licenses/by-nc-nd/4.0/). 
una discusión dirigida interactiva entre el panel de expertos y los asistentes al VI Congreso de la Sociedad Iberoamericana de Oculoplástica, en la que se presentó la experiencia basada en evidencia y personal para la elección del implante ideal en la cavidad anoftálmica. Al encuentro, realizado en el Hospital de Nuestra Señora de la Luz, en Ciudad de México, el 23 de octubre de 2018, asistieron alrededor de 200 médicos oftalmólogos, especialistas en oculoplástica, originarios de Norte, Centro y Sudamérica, así como de España y Portugal. La discusión se centró en los siguientes subtemas: implantes orbitarios en la cavidad anoftálmica, manejo quirúrgico de anoftalmos y criptoftalmos, alternativas a implantes orbitarios. Conclusiones: Los implantes orbitarios que se colocan con mayor frecuencia entre miembros de la SIAO son de acrílico, estos han demostrado buenos resultados a largo plazo, y su principal desventaja es la migración, que, en caso de presentarse, resulta en una rehabilitación secundaria compleja. El injerto dermograso en niños y el lipomicroinjerto en adultos representan también buenas alternativas en el manejo del déficit volumétrico orbitario.

Palabras clave: Cavidad anoftálmica. Evisceración. Enucleación. Implante. Prótesis.

\section{Introduction}

One of the main problems that the oculoplastic ophthalmologist faces when trying to rehabilitate an anophthalmic cavity is the orbital volumetric deficit. To compensate for this problem, different orbital implants of different materials, shapes and sizes have been described. Under these principles it was that, in 1884, Mules developed an evisceration technique with placement of a glass sphere in the remaining sclera, which represented the cornerstone in the efforts for the treatment and rehabilitation of the anophthalmic cavity ${ }^{1-5}$.

Due to the extrusion of glass spheres, various materials (e.g., rubber, wood, marble, cork, silver, gold and others) were subsequently used, and are still in development. From 1989, orbital implants made from silicone, polymethylmethacrylate and, more recently, other biocompatible synthetic polymers emerged ${ }^{6}$.

At present there is no consensus for the volumetric management of the anophthalmic cavity. Due to this, a discussion with experts was raised to know what was described in the literature and their experience, and to determine the best orbital implant currently available under ideal conditions.

\section{Methods}

An interactive directed discussion was held between the panel of experts and those attending the VI Congress of the Ibero-American Society of Oculoplastic, that presented evidence-based and personal experience for the selection of the ideal implant for the anophthalmic cavity.

The meeting was attended by about 200 ophthalmologists specializing in oculoplastic from North, Central and South America, as well as from Spain and Portugal. The discussion focused on the following subtopics: orbital implants in the anophthalmic cavity, surgical management of anophthalmos and cryptophthalmos, alternatives to orbital implants.

The panel of experts was constituted by Dr. Rocío Ardito (Lima, Peru), who explained how to compensate for an ocular prosthesis in a cavity with an orbital volume deficit, Dr. Alejandra Valenzuela (West Forest University, North Carolina, USA), presented the current surgical management of anophthalmos and cryptophthalmos, and Dr. Alfredo Medina (Hospital Regional Lic. Adolfo López Mateos, Instituto de Seguridad y Servicios Sociales de los Trabajadores del Estado (ISSSTE), Mexico), presented other surgical alternatives to traditional orbital implants. The discussion was coordinated by Dr. Ana María Vera (physician and professor of the Oculoplastic Department, Asociación para Evitar la Ceguera en México).

\section{Epidemiology}

Currently, enucleation and evisceration procedures are more common than exenteration ${ }^{7}$. The incidence of enucleation is estimated at 2.8 people per 100,000 inhabitants ${ }^{8}$. In recent decades there has been a change in the trend, from enucleation to evisceration, and the average age of enucleation is approximately at 50 years of age. For a small difference, this type of procedure is more frequently performed in men ${ }^{9}$.

A study in the USA reported an incidence of 2.2 cases of microphthalmos and clinical anophthalmia per 10,000 pregnancies $^{10}$, while studies in the United Kingdom reported an incidence of anophthalmia of 0.6 cases per 100,000 births and 2.5 cases for microphthalmos, without gender predilection ${ }^{11}$.

\section{Etiology and pathogenesis}

Anophthalmic defects occur between days 22 to 27 of gestation $(3 \mathrm{~mm})^{10}$. Primary anophthalmia results 
from a failure at the level of the neural tube ${ }^{12}$, while secondary anophthalmia refers to a degeneration of the optic vesicle after its formation and, as a consequence, neuroectoderm elements ${ }^{13}$ are present. Several genetic mutations have been associated; the first gene identified was the PAX6 gene, although the SOX2 gene is the major cause of this pathology. Other associated causes include rubella, cytomegalovirus, intrauterine exposure to thalidomide, lysergic acid diethylamide (LSD) and vitamin A deficiency ${ }^{14}$.

In adults, the main causes of an anophthalmic cavity include tumors, advanced glaucoma, trauma, infections and other diseases that result in blindness, pain and eyeball morphological changes.

\section{Management}

The orbit acquires approximately $90 \%$ of its final dimensions during the fifth year of life; this is critical to start an effective early treatment ${ }^{15}$. The goal of treatment is to enlarge the orbital bone tissue, as well as the conjunctiva and cul-de-sacs, in order to develop facial symmetry. Initially, shapers should be used. Between ages to 2 and 3 is the limit for using shapers for expansion, and then surgical procedures are necessary to expand the cavity. Surgeries to expand the conjunctival sac include implanting tissue, such as oral or palate mucosa ${ }^{16}$. The expansion of the orbital volume can be achieved by several methods, such as the use of acrylic or polymethylmethacrylate implants. Another option is the use of dermo fat grafts, which have the advantage of providing an excellent volumetric expansion in children.

Patients with midfacial hypoplasia and narrow palpebral fissures should start using shapers from the first month of life, with changes every 4 weeks, until an adequate anteroposterior and lateral volume is achieved. Subsequently, between 18 and 24 months, an implant (diameter of 16 to $18 \mathrm{~mm}$ ) or a dermo fat graft can be used. The placement of both separately is possible between 6 to 24 months of age.

Heterologous orbital implants can be classified as porous or non-porous, and in any category, they can be integrated or not, depending on the connection of the implant with the orbital cavity ${ }^{17}$ (Table 1).

\section{Other alternatives to orbital implants}

Autologous fat graft (Coleman's liposculpture technique) was described for the treatment of facial fat atrophy and has proven useful in increasing orbital
Table 1. Terminology in anophthalmic cavity surgery

\begin{tabular}{l|l}
$\begin{array}{l}\text { Anophthalmic } \\
\text { implant }\end{array}$ & $\begin{array}{l}\text { Material or substance used to replace an } \\
\text { eviscerated or enucleated eye (e.g., } \\
\text { polymethylmethacrylate, silicone, calcium } \\
\text { hydroxyapatite, porous polyethylene) }\end{array}$ \\
\hline Porous implant & $\begin{array}{l}\text { Implant interconnected by pores or channels } \\
\text { through its structure, that allows intrinsic } \\
\text { fibrovascular growth (e.g., hydroxyapatite, } \\
\text { porous polyethylene) }\end{array}$ \\
\hline Non-porous & $\begin{array}{l}\text { Solid implant that does not allow intrinsic } \\
\text { implant } \\
\text { fibrovascular growth } \\
\text { (polymethylmethacrylate, silicone) }\end{array}$ \\
\hline Eye prosthesis & $\begin{array}{l}\text { Ceramic shell or other synthetic material } \\
\text { placed in the anophthalmic cavity - usually } \\
\text { on an orbital implant -, manufactured to } \\
\text { imitate the contralateral eye }\end{array}$ \\
\hline Shaper & $\begin{array}{l}\text { Acrylic shell, with or without fenestrations, } \\
\text { placed on the bulbar conjunctiva, usually } \\
\text { after evisceration or enucleation }\end{array}$ \\
\hline
\end{tabular}

volume in anophthalmic cavities ${ }^{18,19}$. The duration of the graft is variable according to the literature; Coleman reported a graft retention close to $100 \%$ in the nasolabial area ${ }^{20}$, while authors such as Fulton, et al. found a tissue viability of 57 to $100 \%$, depending on the area of grafting ${ }^{21}$.

There are two main factors involved in fat graft survival, these are surgical factors (aspiration, processing and infiltration) and donor site factors. Other related factors include the size and vascularity of the area to be grafted, since areas without a good vascularization may evolve to necrosis and require multiple procedures to achieve satisfactory volumes ${ }^{22}$.

\section{Conclusions}

Acrylic implants continue to be the most used among SIAO members to replenish the volume in anophthalmic cavities, since they have demonstrated predictable effects with lower complications and long-term costs; however, they can also have serious inconveniences, such as migration, which represents a complex therapeutic challenge.

Some possible complications presented by porous implants are erosion of the overlying tissue which facilitates bacterial colonization and may require removal for definitive management. Due to their porous characteristics, removal is usually complex, and involves a long intraoperative period. Some surgeons prefer to guarantee that the infection is controlled prior to a new reconstruction, 
so a second surgery is required for rehabilitation. Likewise, the erosion of the conjunctiva and Tenon's capsule can cause a shortening of the cul-de-sac, creating a greater difficulty for the adjustment of the prosthesis.

Although each case should be individualized, in general, polymethylmethacrylate implants are the preferred ones after evisceration for volumetric rehabilitation, while in cases of enucleation, porous implants may be more effective.

Finally, in terms of alternative methods to traditional implants, dermo fat grafting in children and micro-fat grafting in adults with Coleman's technique are good options, although there is still controversy about the usefulness of centrifugation or fat decantation, as well as the addition of stimulating factors and hormones to improve graft survival during its preparation and grafting.

\section{Conflicts of interest}

The authors declare no conflicts of interest.

\section{Ethical disclosures}

Protection of human and animal subjects. The authors declare that no experiments were performed on humans or animals for this study.

Confidentiality of data. The authors declare that they have followed the protocols of their work center on the publication of patient data.

Right to privacy and informed consent. The authors declare that no patient data appear in this article.

\section{References}

1. Kelley JJ. History of ocular prostheses. Int Ophthalmol Clin. 1970;10:713-9.

2. Gougelmann HP. The evolution of the ocular motility implant. Int Ophthalmol Clin. 1976;689-711.

3. Snyder C. An operation designated the extirpation of an eye. Arch Ophthalmol. 1965;74:429-34.

4. Rudemann AD. Modified Burch type evisceration with scleral implant. Am J Ophthalmol. 1960;49:41-4.

5. Mules PH. Evisceration of the globe with artificial vitreous. Trans Ophthalmol Soc UK. 1885;5:200-6.

6. Hornblass A, Beisman BS, Eviator JA. Current techniques of enucleation: a survey of 5,439 implants and a review of the literature. Ophthal Plast Reconstr Surg. 1995;11:77-88.

7. Kitzmann AS, Weaver AL, Lohse CM, Buettner H, Salomão DR. Clinicopathologic correlations in 646 consecutive surgical eye specimens, 19902000. Am J Clin Pathol. 2003;119(4):594-601.

8. Erie JC, Nevitt MP, Hodge D, Ballard JD. Incidence of enucleation in a defined population. Am J Ophthalmol. 1992;113(2):138-44.

9. De Gottrau P, Holbach LM, Naumann GO. Clinicopathological review of 1146 enucleations (1980-90). Br J Ophthalmol. 1994;78(4):260-5.

10. Heinonen OP, Sloan D, Shapiro S. Birth defects and drugs in pregnancy. Publishing Sciences Group: New York; 1977.

11. Shaw GM, Carmichael SL, Yang W, Harris JA, Finnell RH, Lammer EJ. Epidemiologic characteristics of anophthalmia and bilateral microphthalmia among 2.5 million births in California, 1989-1997. Am J Med Genet A. $2005 ; 137(1): 36-40$.

12. Smith CG, Gallie BL, Morin JD. Normal and abnormal development of the eye.Crawford JS, Morin JD. The eye in childhood. Grune \& Stratton: New York; 1982. p. 1-18

13. Fitzpatrick DR, van Heyningen V. Developmental eye disorders. Curr Opin Genet Dev. 2005; 15:348-53.

14. Katowitz JA. Pediatric oculoplastic surgery. Springer Verlag: New York; 2002. p. 180-3.

15. Ahn JM, Lee SY, Yoon JS. Health related quality of life and emotional status of anophthalmic patients in Korea. Am J Ophthalmol. 2010;149:1005-11.

16. Ibanga A, Asana U, Nkanga D, Duke R, Etim B, Oworu O. Indications for eye removal in southern Nigeria. Int Ophthalmol. 2013;33(4):355-60.

17. Jordan DR. Localization of extraocular muscles during secondary orbital implantation surgery. The tunnel technique: experience with 100 patients. Ophthalmology. 2004;111:1048.

18. Coleman SR. Facial recontouring with lipostructure. Clin Plast Surg 1997;24:347-67.

19. Malet T. Reinjection of autologous fat in moderately deep upper lid sulci of anophthalmic sockets. Orbit. 2000;19:139-51.

20. Coleman SR. Long-term survival of fat transplants: controlled demonstrations. Aesthetic Plast Surg. 1995;19:421-5.

21. Fulton JE, Parastouk N. Fat grafting. Dermatol Clin. 2001;19:523-30.

22. Yazawa M, Mori T, Tuchiya K, Nakayama $Y$, Ogata $H$, Nakajima T. Influence of vascularized transplant bed on fat grafting. Wound Repair Regen. 2006;14:586-92. 